\section{HIGHS AND LOWS OF FAMILY LAW REFORM}

The tenth anniversary of the coming into force of the Children Act 1989 occurs this year on 14 October and it seems timely to look at the way in which this major piece of family law reform, and others, have come about (or not, as in the case of Part II of the Family Law Act 1996, which is to be repealed). The Children Act 1989 is perhaps the prime example of successful family law reform, emerging from a great deal of consultation by the Government and the Law Commission by way of a major Law Commission report, an Interdepartmental Government Child Care Law Review and a review of the law concerning residential homes and other forms of child care. Two years of careful preparation and an unprecedented level of training followed Royal Assent. While the Act would be improved by a number of changes, it has stood the test of time extremely well. One has high hopes for the Adoption and Children Bill (which fell with the dissolution of Parliament but is to be re-introduced), which will effect some of those useful changes.

It was certainly a precept of Lord Chancellor Hailsham, who was responsible for a number of family law reform measures, that law reform is by consent or not at all. However, the history of divorce law reform from A.P. Herbert's Matrimonial Causes Act 1937 (which provided for equality of treatment between men and women, and three new grounds for divorce, namely cruelty, incurable insanity and three years' desertion - the 'Bad', the 'Mad' and the 'Bolters') onwards, shows that even when reform is generally welcome it can all too easily be blown off course. Following the Church of England's 'Putting Asunder' and the Law Commission's report on divorce in 1966, it was Leo Abse MP who bravely introduced the Divorce Reform Act 1969 as a Private Member's Bill. The underlying intention was to 'Bring to an end marriages which had become no more than a hollow shell'. However, to dissolve marriage without a 'guilty' party was more than some MPs (and constituents) could accept. So the Bill emerged onto the statute book as a rather nasty hybrid which made the sole ground for divorce the irretrievable breakdown of marriage, but then required proof of breakdown to be established by one or more of five facts - three of which clearly retained the concept of the matrimonial 'offence'

The Matrimonial Proceedings and Property Act 1970 (consolidated with the 1969 Act in the Matrimonial Causes Act 1973) was a much less controversial measure, though it had a more fundamental effect upon the divorcing population perhaps than the 1969 Act. It certainly stirred up a lot of divorcing men who found that they were not only paying maintenance for former wife (and child) but now were expected to give up a share of their property and savings!

Another 1970s Act, which had a chequered Parliamentary history, was the Domestic Violence and Matrimonial Proceedings Act 1976 - a Private Member's Bill introduced by the late Jo Richardson MP. The thought that a chap could be thrown out of his own home, even temporarily, by his wife - or even worse his mistress - was too much for some on the then Opposition benches, especially one-armed Willy Rees-Davies MP, who under the then prevailing arcane procure for private Bills had it talked out at second reading. However such was the uproar in the Chamber - the proceedings were brought to a halt for a full ten minutes - that the Government found time for it to complete its second reading. The fact that over 2,000 non-molestation and exclusion orders were made in the first 12 months of its being in force demonstrated the need for this reform.

What appeared to be a well researched and consulted measure, based largely on four Law Commission reports, was the Matrimonial and Family Proceedings Act 1984. But its reforms of the three-year discretionary bar on petitioning for divorce and the introduction of the 'clean break' in respect of financial orders turned out to be surprisingly controversial. The former provision in particular gave rise to arguments about encouraging people to marry in haste and divorce in equal haste, repeatedly, and a heated riposte by Lord Chancellor Hailsham, during second reading, to crush the unfortunate Bishop of Norwich, who was told among other things that he, Hailsham, had been a practising Christian for longer than the Bishop and probably had a better grasp on the Scriptures concerning marriage than did the Bishop.

\section{Articles}

Human Rights in the Isle of Man: the administrative/judicial discretion debate

Globalisation and private international law: reviewing contemporary law

A race apart?

Institute News

Society News

\section{Articles cont'd}

Land Registration, Conveyancing and Property Markets: The Edwards Report, June 200119

Partnership law for the new millennium

The impact of the Human Rights Act 1998 on evidence and disclosure in judicial review proceedings 27

\section{Letter from...}

America

The family law reformer is always faced with the problem of narrow sectional interests, where emotion rather than reason dominates. The campaign by The Daily Mail and the Reverend Oddy in respect of Part II of the Family Law Act 1996 is the latest example. What emerged from the Law Commission as a well thought out and carefully structured measure, designed to reduce the emotional trauma of divorce for couples whose relationship had broken down, and for children whose parents had separated, emerged from Parliament as a measure designed to create problems for spouses through its complexity, and greater delay and misery for children. The Lord Chancellor announced earlier this year that the research carried out by Newcastle University revealed that the system of information meetings upon which Part II hinges had proved unworkable in the pilot projects set up to test it. The Government accordingly intends to repeal Part II of the 1996 Act.

It is clear that important and valuable improvements to family law can be achieved by thorough consultation leading to well constructed, workable legislation. Regrettably, where emotions are roused, Parliament is not a good place to pursue well-reasoned measures with an expectation of good law emerging at the end of the Parliamentary process. I must confess here that my experience of handling family law reform Bills has left me with a somewhat jaundiced view of the democratic process in action! Nevertheless, the experience of the Children Act provides a model for achieving significant advances - as well as emphasising the importance of putting resources into training and educating those who have to implement and operate major changes in the law. Let us hope that it will prove to be the case that implementation of the Adoption and Children Bill follows the example provided by the Children Act 1989 .

\section{Peter Harris}

The author is the former Official Solicitor 